\title{
ЭФФЕКТИВНОСТЬ СОЛЕЙ ЩЕЛОЧНОЗЕМЕЛЬНЫХ МЕТАЛЛОВ В РЕАКЦИИ ОКИСЛЕНИЯ ТОЛУОЛА ДО БЕНЗИЛОВОГО СПИРТА
}

\author{
(Представил О. Киррет)
}

Бензиловый спирт используется в химической, текстильной, парфюмерной, фармацевтической, лакокрасочной промышленности $\left[{ }^{1,2}\right]$.

Основным методом получения бензилового спирта является омыление хлористого бензила водным раствором соды или щелочи [3]. Продукт, полученный таким образом, содержит примеси хлорсодержащих соединений и имеет высокую себестоимость.

Более прогрессивными являются разрабатываемые в ряде стран методы получения бензилового спирта прямым окислением толуола. При этом наряду с целевым продуктом образуется целый ряд соединений, в том числе бензойная кислота и бензальдегид. Основное затруднение всех способов, использующих прямое окисление толуола, состоит в том, что бензиловый спирт, образующийся на начальной стадии окисления и являющийся промежуточным продуктом, окисляется значительно легче, чем толуол, а применяемые катализаторы ускоряют все стадии процесса. Поиск путей увеличения выхода бензилового спирта направлен на подбор селективных катализаторов и соответствующих технологических параметров.

Процесс получения бензилового спирта окислением толуола защищен множеством патентов. Продукт получается высокого качества, но выход его на загруженный толуол обычно не превышает $2 \%$.

Согласно [4, 5], металлы постоянной валентности инициируют образование гидроперекиси, а также служат катализатором ее разложения при окислении алкилароматических углеводородов, в частности изопропилбензола. Сообщается [6], что гетерогенные катализаторы при окислении органических соединений ускоряют только распад перекиси и не участвуют в реакциях продолжения цепи.

В настоящей работе исследована каталитическая активность ряда нерастворимых в углеводородах неорганических солей щелочноземельных металлов и их же в смеси со стеаратом марганца в процессе окисления толуола до бензилового спирта.

Марганец известен как один из наиболее активных катализаторов жидкофазного окисления, применяемый и для получения бензилового спирта. Предполагалось, что с использованием гетерогенных катализаторов на базе солей щелочноземельных металлов будет получен более высокий выход бензилового спирта и повышена селективность его образования.

Толуол ч. д. а. подвергали окислению воздухом при $180^{\circ} \mathrm{C}$ и давлении 0,65 МПа. В качестве катализаторов использовали безводные соли ч. д. а. в виде порошка. Для определения влияния механической обработки гетерогенного катализатора на его активность соли щелочноземельных металлов пропускали через лабораторный дезинтегратор с четырехряд- 
ными роторамй при часстоте вращения 167 и $300 \mathrm{c}^{-1}$ в течение $10 \mathrm{c}$. Стеарат марганца не обрабатывали.

Опыты по окислению толуола проводили на лабораторной установке периодического действия (рис. 1). В колонный барботажный реактор (4), снабженный электрообогревом, загружали 3,0 моля толуола, $1,26 \cdot 10^{-2}$ моля соли щелочноземельного металла и $6,4 \cdot 10^{-4}$ моля стеарата марганца. Из баллона (1) через редуктор (2) и ротаметр (3) в нижнюю часть реактора окисления непрерывно подавали воздух. Парогазовую смесь из реактора охлаждали в холодильнике (6), снабженном водяной рубашкой. Конденсат стекал в сепаратор (5), где происходило расслаивание. Органический слой возвращали в реактор, а реакционную воду выводили из процесса. Несконденсированные газы сбрасывали в атмосферу. Постоянный расход воздуха и давление в системе регулировали при помощи игольчатых вентилей. Температуру в реакторе поддерживали постоянной с помощью автоматического регулятора (7), а контроль над ней осуществляли потенциометром (8) с термопарой. Отбор проб и выпуск реакционной смеси (оксидата) производили через вентиль в нижней части реактора. За начало опыта принимали время, когда температура в реакторе достигала заданного значения.

По ходу процесса через каждые 5 мин отбирали пробы для определения состава оксидата. Количество перекиси определяли иодометрически, кислот (бензойной) - титрованием едким натром. Содержание нейтральных соединений определяли на хроматографе ЛХМ-8МД с пламенно-ионизационными детекторами (рис. 2). Кинетика накопления бензилового спирта носит экстремальный характер. В каждом опыте брали максимальные концентрации бензилового спирта и рассчитывали селективность его образования.

Расчеты показали, что соли щелочноземельных металлов в чистом виде проявляют слабую каталитическую активность, которая существенно не изменяется после их механической обработки в дезинтеграторе (таблица). Замена катиона щелочноземельного металла в хлоридах, а

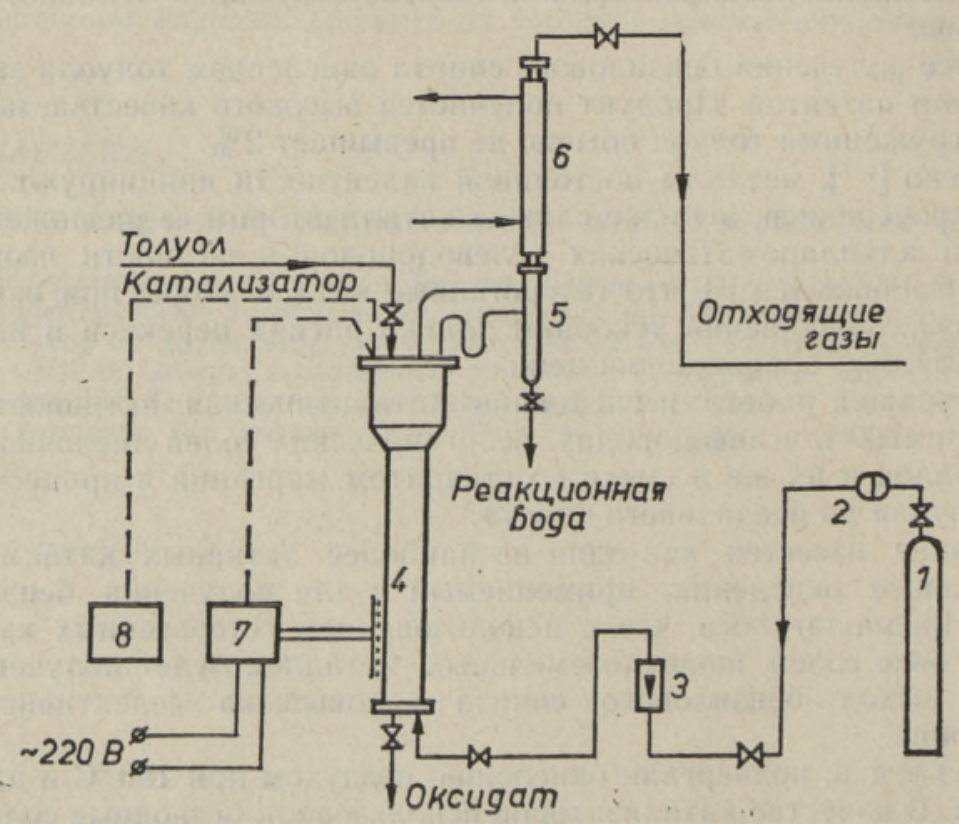

Рис. 1. Схема лабораторной установки окисления толуола: 1 - баллон со сжатым воздухөм, 2 - редуктор, 3 - ротаметр, 4 - реактор окнсления, 5 - сепаратор, 6 - холодильник, 7 - регулятор температуры, 8 - потенциометр. 
Conоставление эффективности солей щелочноземельных металлов и их же в смеси со стеаратом марганца при окислении толуола до бензилового спирта

\begin{tabular}{|c|c|c|c|c|c|}
\hline \multirow{3}{*}{$\begin{array}{c}\text { Соль щелочно- } \\
\text { земельного } \\
\text { металла }\end{array}$} & \multirow{3}{*}{$\begin{array}{c}\text { Частота } \\
\text { вращения } \\
\text { ротора дез- } \\
\text { интегратора } \\
\text { при обра- } \\
\text { ботке ка- } \\
\text { тализатора, } \\
\text { с }^{-1}\end{array}$} & \multicolumn{2}{|c|}{$\begin{array}{c}\text { Без стеарата } \\
\text { марганца }\end{array}$} & \multicolumn{2}{|c|}{$\begin{array}{c}\text { Со стеаратом } \\
\text { марганца }\end{array}$} \\
\hline & & \multicolumn{4}{|c|}{ Образование бензилового спирта } \\
\hline & & $\begin{array}{c}\text { содержание } \\
\text { в оксида- } \\
\text { те, } \%\end{array}$ & $\begin{array}{l}\text { селектив- } \\
\text { ность, } \%\end{array}$ & $\begin{array}{c}\text { содержание } \\
\text { в оксида- } \\
\text { те, \% }\end{array}$ & $\begin{array}{l}\text { селектив- } \\
\text { ность, \% }\end{array}$ \\
\hline $\begin{array}{c}\text { Хлорид магния } \\
, \\
,\end{array}$ & $\begin{array}{l}\overline{167} \\
300\end{array}$ & $\begin{array}{l}0,23 \\
0,20 \\
0,24\end{array}$ & $\begin{array}{r}10,1 \\
11,7 \\
9,8\end{array}$ & $\begin{array}{l}1,67 \\
1,76 \\
1,67\end{array}$ & $\begin{array}{l}29,3 \\
27,7 \\
28,9\end{array}$ \\
\hline $\begin{array}{c}\text { Хлорид бария } \\
, " \\
, "\end{array}$ & $\begin{array}{l}\overline{167} \\
300\end{array}$ & $\begin{array}{l}0,13 \\
0,19 \\
0,11\end{array}$ & $\begin{array}{r}10,5 \\
8,8 \\
11,6\end{array}$ & $\begin{array}{l}1,76 \\
1,80 \\
1,69\end{array}$ & $\begin{array}{l}25,8 \\
26,0 \\
28,5\end{array}$ \\
\hline $\begin{array}{c}\text { Хлорид кальция } \\
\text { ", }\end{array}$ & $\begin{array}{l}\overline{167} \\
300\end{array}$ & $\begin{array}{l}0,19 \\
0,17 \\
0,21\end{array}$ & $\begin{array}{l}13,1 \\
10,7 \\
12,5\end{array}$ & $\begin{array}{l}1,73 \\
1,67 \\
1,85\end{array}$ & $\begin{array}{l}27,5 \\
29,1 \\
26,6\end{array}$ \\
\hline $\begin{array}{c}\text { Фторид кальция } \\
, " \\
,\end{array}$ & $\begin{array}{l}\overline{167} \\
300\end{array}$ & $\begin{array}{l}0,15 \\
0,12 \\
0,14\end{array}$ & $\begin{array}{r}7,3 \\
11,4 \\
10,4\end{array}$ & $\begin{array}{l}1,68 \\
1,70 \\
1,85\end{array}$ & $\begin{array}{l}28,7 \\
27,4 \\
26,3\end{array}$ \\
\hline $\begin{array}{c}\text { Сульфат кальция } \\
\text { " } \\
,\end{array}$ & $\begin{array}{l}\overline{167} \\
300\end{array}$ & $\begin{array}{l}0,17 \\
0,18 \\
0,13\end{array}$ & $\begin{array}{r}9,8 \\
11,0 \\
10,2\end{array}$ & $\frac{1,65}{1,72}$ & $\frac{28,1}{25,9}$ \\
\hline
\end{tabular}

также аниона в солях кальция не влияет на активность катализатора. Селективность образования бензилового спирта составляет $7,3-13,1 \%$ при концентрации его в оксидате $0,11-0,24 \%$.

В опытах с применением чистого стеарата марганца получена концентрация бензилового спирта в оксидате 1,4\% при селективности его образования $20,6 \%$.

При использовании в качестве катализаторов смесей солей щелочноземельных металлов со стеаратом марганца селективность образования бензилового спирта возрастает до $25,8-29,3 \%$, а его концентрация в оксидате достигает $1,65-1,85 \%$. Как и в случае чистых неорганических солей щелочноземельных металлов, не отмечено влияния механической обработки этих солей на их каталитическую активность.

Рис. 2. Хроматограмма оксидата: $I$ - ацетон (растворитель) +толуол, 2 - бензальдегид, 3 - ацетофенон, 4 - бензилформиат, 5 бензилацетат, 6 - бензиловый спирт, 7 - м-крезол (стандарт), 8 - дифенил, 9 - дифенилметан, $10-$ дифенилэтан, 11 - бензойная кислота, 12 - дибензиловый эфир, 13 - бензилбензоат.

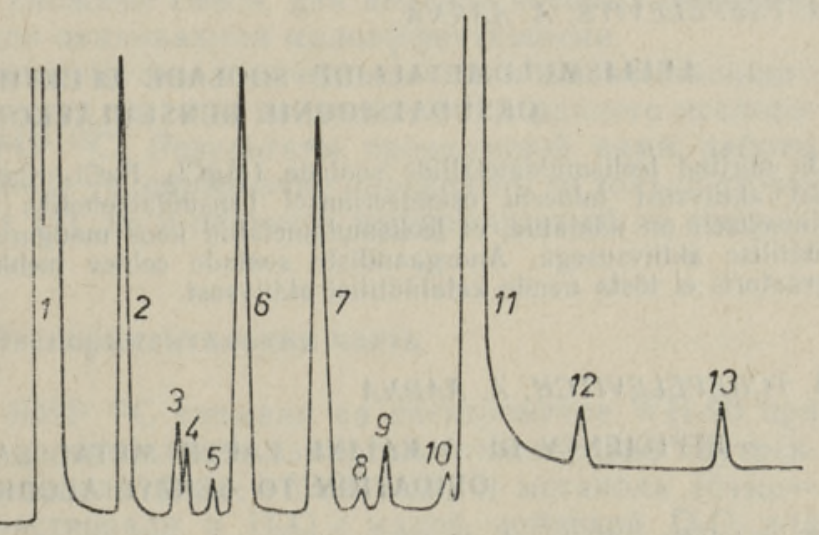

Условия хроматографирования: колонка 1 м 3 мм, неподвижная фаза - хроматон N-AW $(0,25-0,40$ мм) + полиэтиленгликольадипинат, апиезон $\mathrm{L}$ н фосфорная кислота в количестве 15,5 и $2 \%$ соответственно; температура испарителя $280^{\circ} \mathrm{C}$; скорость газа-носителя (азота) - 35 мл/мин; программирование температуры от 110 до $190^{\circ}$ со скоростью $3 \%$ мин; внутренний стандарт - 
Достигнутая концентрация бензилового спирта в случае применения смеси катализаторов превышает суммарную концентрацию спирта при использовании отдельно взятых солей. Отсюда следует, что смесь соли марганца и щелочноземельных металлов проявляет слабо выраженный синергизм при катализе окисления толуола до бензилового спирта.

\section{Выводы}

1. Неорганические соли щелочноземельных металлов обладают низкой каталитической активностью в реакции окисления толуола до бензилового спирта.

2. Механическая обработка неорганических солей щелочноземельных металлов не изменяет их каталитической активности.

3. Смесь солей марганца и щелочноземельных металлов проявляет слабо выраженный синергизм при катализе окисления толуола до бензилового спирта.

\section{ЛИТЕРАТУРА}

1. Watanabe, M., Namikawa, $K$. Benzyl alcohol - its manufacturing processes and uses. - Chem. Econ. and Eng. Rev., 1970, 2, N 3, 50-52.

2. Перазич Д. И., Соколова А. И., Акимов С. А. Применение бензилового спирта и методы его получения. М., 1979.

3. Шулов Л. М., Лещинер А. С. Справочник по душистым веществам и другим синтетическим продуктам парфюмерно-косметической промышленности. М., 1972.

4. Цысковский В. К., Москович Ю. Л. Особенности реакции окисления углеводородов в гидроперекиси, катализированной солями металлов постоянной валентности. - Кинетика и катализ, 1974, XV, вып. 6, 1466-1469.

5. Цысковская И. В., Овчинников В. И., Потехин В. М., Хачатуров А. С. О механизме каталитического разложения моногидроперекиси пара-диизопропилбензола. Ж. прикл. хим., 1980, LIII, № 4, 783-787.

6. Blažek, V., Subčik, L., Setinek, $K$. Decomposition of hydrogen peroxide by heterogenized cobalt acetate complexes. - Collect. Czech. Chem. Communs, 1982, $47, \mathrm{~N} 8,2227-2234$.

\section{НИИ сланщев}

Институт химии

Академии наук Эстонской ССР

Поступила в редакцию $2 / \mathrm{IX} 1985$

\section{A. TSEPELEVITS, A. AARNA}

\section{LEELISMULDMETALLIDE SOOLADE EFEKTIIVSUS TOLUEENI OKSODATSIOONIL BENSUOLALKOHOLIKS}

On uuritud leelismuldmetallide soolade $\left(\mathrm{MgCl}_{2}, \mathrm{BaCl}_{2}, \mathrm{CaCl}_{2}, \mathrm{CaF}_{2}, \mathrm{CaSO}_{4}\right)$ katalüütilist aktiivsust tolueeni osküdeerimisel bensüülalkoholiks manganstearaadi manulusel. Katseliselt on näidatud, et leelismuldmetallid koos manganstearaadiga on madala katalüütilise aktiivsusega. Anorgaaniliste soelade eelnev mehhaaniline töötlemine desintegraatoris ei tõsta nende katalüütilist aktiivsust.

\section{A. TCHEPELEVITCH, A. AIARNA}

\section{EFFICIENCY OF ALKALINE EARTH METAL SALTS AT TOLUENE OXIDATION TO BENZYL ALCOHOL}

The catalytic activity of alkaline earth metal salts $\left(\mathrm{MgCl}_{2}, \mathrm{BaCl}_{2}, \mathrm{CaCl}_{2}, \mathrm{CaF}_{2}, \mathrm{CaSO}_{4}\right)$ at toluene oxidation to benzyl alcohol was studied in the presence of manganese stearate. Experiments showed that alkaline earth metals together with manganese stearate have a low catalytic activity. The mechanical pretreatment of inorganic salts in a desintegrator does not increase their catalytic activity, either. 